\title{
De-Shadowization of Tax Gaps in the System-Compositional Models of State Fiscal Policy: Comparative Analysis of EU Countries and Ukraine
}

\author{
Natalia V. Trusova \\ Dmytro Motornyi Tavria State Agrotechnological University \\ 72310, 18 B Khmelnitsky Ave., Melitopol, Ukraine \\ Oksana V. Hryvkivska \\ European University \\ 02200, 16 B Akademik Vernadsky Blvd., Kyiv, Ukraine \\ Nataliia V. Polishchuk \\ Vinnytsia Finance and Economics University \\ 21037, 7la Pyrohov Str., Vinnytsia, Ukraine \\ Svitlana V. Skrypnyk \\ Kherson State Agrarian and Economic University \\ 73006, 23 Stritenska Str., Kherson, Ukraine
}

Iryna F. Lobacheva

Vinnytsia Institute of Trade and Economics of the Kyiv National University of Trade and Economics 21050, 87 Soborna Str., Vinnytsia, Ukraine

Olena M. Kudyrko

Vinnytsia Institute of Trade and Economics of the Kyiv National University of Trade and Economics 21050, 87 Soborna Str., Vinnytsia, Ukraine

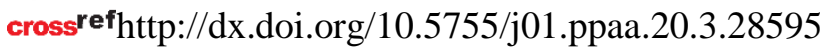

\begin{abstract}
The purpose of the article is to consider the empirical calculations of the level of de-shadowization of tax gaps in the system-compositional model of the fiscal policy of the state. The methodological approach to cointegration of the level of de-shadowization of tax gaps into the system-compositional model of fiscal policy is substantiated, taking into account the strategic determinants of financial and economic development of the state. The method of calculation of the integrated indicator of strategic alternatives is presented and represents the configuration of the modified system of fiscal innovations in relation to the taxation of economic entities. A methodical approach to estimating the level of de-shadowization of the tax gap on the income tax of economic entities is proposed. The level of unit testing of variables of de-shadowization of tax gaps from indicators of financial and economic development of the EU and Ukraine is analyzed. It is concluded that one of the most influential factors today is the de-shadowization of the economy. The future directions are the research of the ways to improve Ukraine's fiscal policy.
\end{abstract}

Keywords: tax burden, tax revenues, income tax, budget and tax sphere.

Raktažodžiai: mokesčiu našta, mokestinès pajamos, pajamu mokestis, biudžetas ir mokesčiu sritis

\section{Introduction}

The current economic system distorts the economy and entrepreneurial activity, and ultimately leads to the transition of market structures in the shadow sector, reducing the quality and efficiency 
of the entire economic system. It is necessary to develop fundamentally new approaches to the deshadowing of the national economy which would take into account not only hidden socio-economic interactions, but also the real possibilities of the state to regulate them, because further ignoring the shadowing mainly leads to even greater shadowization of the economic system. It should be noted that shadow activity exists in all countries and threatens the stability of such fundamental institutions as the legal and fiscal systems. The latter is beginning to counteract the various forms and directions of the shadow sector of the economy, forming a single and stable system. Evasion of economic agents from fulfilling their tax obligations leads to the formation of tax gaps. At the same time, unregulated fiscal policy, when changing the strategy of macroeconomic development and transformation of economic and legal relations, increases the influence of external factors on the shadowing of the national economy. This leads to ineffective government policies for the development of socioeconomic determinants and the management of tax gaps (Dunets et al., 2019; Ivanishina and Hirna, 2018).

Financial and economic principles of de-shadowization of the economy are discussed in the works of the following scientists: Cpa (2015), Enste (2015), Kriuchkova (2016), Mazur (2014) and Sokolovska (2012). Scientists, including Brooks, Godfrey, Hillenbrand and Money (2016), Harremi (2014),. Mitra (2017) have made a significant contribution to the development of the theoretical basis of the management of tax gaps. The issue of formation and implementation of fiscal policy in the national context and the general impact on the results of the socio-economic development of the state was dealt with in work by Baunsgaard and Keen (2019), Bohatyrova (2016), Krysovatyi, Melnyk and Koshchuk (2014). The priority of our study is to develop a new methodological approach to the integration of the level of de-shadowization of tax gaps in the system-compositional model of fiscal policy, taking into account the strategic determinants of the financial and economic development of the state. This study begins with the background of the study, afterwards, the research method and the results are presented. Finally, we conclude with a discussion and limitations of the study.

\section{Materials and Methods}

The mechanism of de-shadowization of tax gaps in the state combines budget-tax indicators which embody the mobilized volumes of taxes, the distribution of which is achieved through formative monetary instruments and fiscal policy. At the same time, each fiscal instrument is supposed to achieve a super-additive effect on the state economy, which is mutually consistent in the budget and tax sphere through: 1) tax regulation, which ensures the effectiveness of existing means of tax incentives for the economy; 2) budget regulation, which improves the principles of budget formation and restrictions on the expansion of state budget expenditures. The proposed model of choosing strategic alternatives for de-shadowization tax gaps in the system-compositional model of fiscal policy of the state is an architecture of interconnected and complementary indicators of the budget and tax sphere, reproducing the chain of general determinants of financial and economic development (Figure 1).

The application of the fractal theory allows to adapt the relationship between the indicators of the fiscal sphere and the efficient allocation of additional financial resources in order to support fiscal innovations in the state. The top of the structure of indicators of the budget and tax sphere, which have a systemic nature of the implementation of measures to de-shadowization of tax gaps, is formed by the fractal $\mathrm{V}(\mathrm{G})$, as a set of components: (S) is socio-psychological component, (O) is organizational component, $(\mathrm{PB})$ is the period of introduction of determinants of financial and economic development in the budget and tax sphere, (E) is fixed weight of the effect of the proposed indicators of financial and economic development of the state in the budget and tax sphere. At the same time, the functions (E_ij, B_ij) are distinguished, where $E_{-}$ij is the effect of the introduction of indicators of the budget and tax sphere and the planned measures of de-shadowing of tax gaps; $\mathrm{B}$ _ij is costs for the implementation of the planned measures to de-shadowization tax gaps (Panura, 2019; Kucheryavenko and Smychok, 2019). 


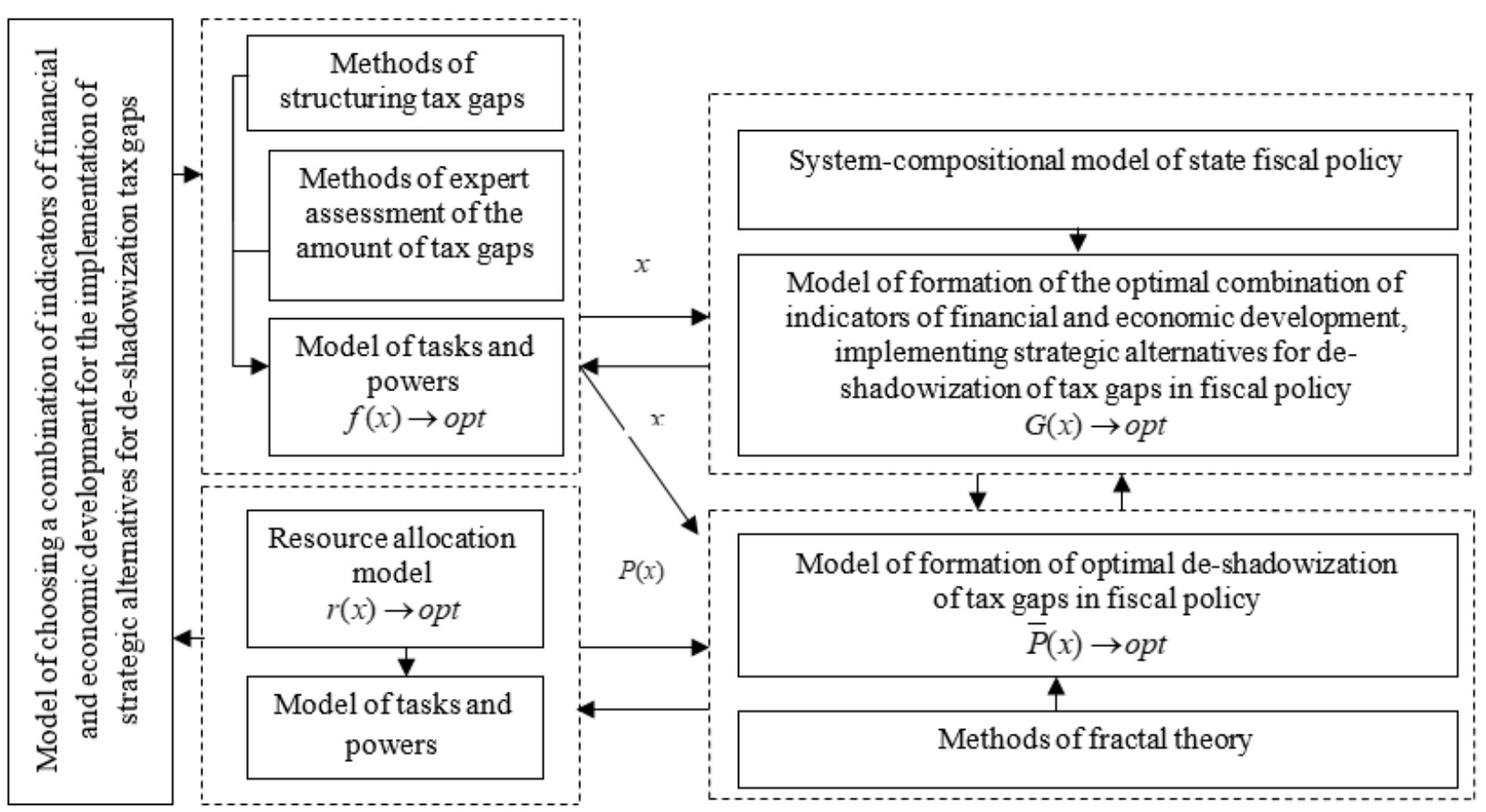

Figure 1. The choice of strategic alternatives for de-shadowization of tax gaps in the systemcompositional model of the state fiscal policy

Source: Authors.

The application of the components of the implementation of measures to de-shadowization of tax gaps allows to form additional costs for their implementation, taking into account the risks of changes in the budget and tax sphere, with limitation and optimization of time limits in fiscal innovations (1-3):

$$
\begin{gathered}
\sum^{\Sigma} E_{i} \rightarrow \max , \\
R_{a c t}^{i}(t)-R_{p l}^{i} \rightarrow \min , \\
t^{+}\left(x_{i}\right)-t^{-}\left(x_{i}\right) \rightarrow \min ,
\end{gathered}
$$

where, $x_{i}$ is a certain measure; $R_{p l}^{i}$ is forecast costs for the implementation of fiscal innovations according to the planned measures to de-shadowization of tax gaps; $R_{a c t}^{i}(t)$ is actual costs; $E_{i}$ is the effect of the introduction of innovations in the budget and tax sphere with a time limit of financial fluctuations from the de-shadowization of tax gaps; $t_{i}$ is time limits for the implementation of measures.

The level of de-shadowization of tax gaps in diagnosing indicators of financial and economic development of the state corresponds to the selected measures of strategic alternatives (4-6):

$$
\begin{gathered}
|f(K)-f(\xi)| \rightarrow \min , \\
f(K)=\sum_{i=1}^{n} \alpha \times f_{i}(K), \\
a \leq f(k) \leq b,
\end{gathered}
$$

where: $n$ is the number of analytical indicators; $f(K)$ is integrated assessment of indicators of financial and economic development of the state in selected measures of strategic alternatives for deshadowization of tax gaps; $k_{i} \in[a, b]$ is the lower and upper value of the assessment of indicators of financial and economic development of the state in the selected measures of strategic alternatives for de-shadowization of tax gaps; $\alpha$ is projected assessment of indicators of the financial and economic development of the state in selected measures of strategic alternatives for de-shadowization 
of tax gaps; $f(\xi)$ represents real results from the introduction of measures to de-shadowization of tax gaps on the selected strategic alternatives (Sheverdin, 2018; Vatamaniuk, 2018).

Given the complexity of assessing the effect of the proposed indicators of the financial and economic development of the state, ensuring the implementation of planned measures to de-shadow tax gaps, it is proposed to use an integrated indicator of strategic alternatives, which embodies the configuration of a modified system of fiscal innovations. Accordingly, the model for estimating the level of de-shadowization of tax gaps $(Q)$ is as follows (Harremi, 2014; Trusova et al., 2019) (7):

$$
K(Q)=\phi\left(K\left(x_{1}\right), \ldots, K\left(x_{n}\right)\right)=\sum_{j=1}^{m} \sum_{l=1}^{n} b_{j} \times k_{i}\left(x_{i}\right),
$$

where: $K(Q)$ is integrated assessment of the level of de-shadowization of tax gaps; $k_{i}\left(x_{i}\right)$ is the assessment of the $i$-strategic alternative to de-shadowization tax gaps on the $i$-th indicator of the budget and tax sphere $k_{i} \in K ; b_{j}$ is the importance of the analytical indicator of financial and economic development of the state as a whole.

Analyzing the following schemes, it is necessary to distinguish between tax fraud and tax evasion, which are illegal attempts to partially or completely avoid the fulfilment of tax obligations (e. g., concealment or understatement of sources of income, overstatement of expenses); avoid tax by streamlining the taxpayer's business to reduce his tax liability. In addition, the schemes provide for a change in the amount of debt, strategic pricing for transfers and strategic location of intangible assets structured for tax purposes (debt structuring, transfer pricing, change of location of individual business units, intangible assets, etc.) (Trusova et al., 2018). Thus, the precondition for a tax gap in the economy is not only a low level of tax morale among taxpayers but also the objective complexity of fiscal policy, insufficiently clear tax legislation and imbalances in the economy, which cause insolvency of economic entities. Macroeconomic methods of estimating the income tax gap of economic entities in accordance with the sources of information on the existing tax base can be divided into three main groups:

1. Methods of national accounts within which the calculation of the theoretical tax liability involves the application of the methodology for estimating the gap in corporate income tax (CIT), which connects the concepts of the gap, i.e., the basic gap for CIT and the potential gap for CIT. The basic gap is the difference between the potential and declared tax base, taking into account the volume of financial transactions carried out in the current year. The potential CIT gap is the difference between a potential liability under the income tax base (i.e., the amount of tax declared and a potential one, provided that all taxpayers complied with tax law) and the amount of actually declared liability with CIT.

2. Macro Model Methods, which are based on the use of the relationship between the amount of cash $(M)$ in circulation and the speed of its circulation in the economy $(V)$, necessary to obtain GDP $(Y)$. Any deviation between the observed GDP $(Y)$ and the theoretical GDP can be considered as the shadowization of the economy (8):

$$
Y=M \times V,
$$

3. The method of econometric assessment of the elasticity of the declared income from the level of taxation allows estimating the real distribution of profit between the actually declared (which is the basis for determining the tax liability of the taxpayer) and income moved abroad for tax reasons. We should note that the change in the rate of return in developing countries is considered in the context of moving the tax base. The assessment of the scale and nature of the movement of tax bases are carried out using regression analysis and involve testing the validity of the hypothesis of the impact of tax rates in one country on the amount of tax base in another one (Baunsgaard and Keen, 2019). The amount of the basic movement of the tax base is determined using the equation (9):

$$
b_{i t}=b_{i t-1}+\tau_{i t}+(W-i \tau-i t)+X_{i t}+\alpha_{i}+\mu_{t}+\phi_{i t},
$$


where: $b_{i t}$ is the base of taxation of income tax of the economic entity in the country $i=$ $1, \ldots, n$ for the period $t=1, \ldots, L$ (with a lag as an independent variable); $\tau_{i t}$ is the rate of income tax of the economic entity; $W-i \tau-i t$ is weighted average values $\sum_{j \neq 1}^{n} \omega_{i t} \times \tau_{i t}$ of statutory income tax rates of economic entities in countries $j \neq 1$ (with $\sum_{j \neq 1}^{n} \omega_{i t}=1$ ); $X_{i t}$ is vector of government elements; $\alpha_{i}$ and $\mu_{i}$ is the influence of factors of the country and time; $\phi_{i t}$ is short-term marginal impact of the income tax rate of economic entities of the country on the volume of its own tax base.

The efficiency of corporate income tax in the country $\left(E_{i}\right)$ can be defined as the ratio of actual income tax revenues of economic entities $\left(R_{i}\right)$ to its reference level (i.e., the product of the standard tax rate $\left(t_{i}\right)$ on the theoretical basis of taxation $\left.\left(G_{i}\right)\right)(10)$ :

$$
E_{i t}=\frac{R_{i}}{t_{i} \times G_{i}}
$$

If the coefficient is lower than one, it indicates that the current taxation system does not provide an opportunity to increase revenues compared to the standard. The difference in the effectiveness of corporate income tax systems between countries shows the presence (absence) of tax benefits, tax holidays, reduced tax rates, as well as the level of tax morale of the population, reactions to changes in the economic situation (i.e., changes in profits). It should be noted that transnational companies (TNCs) use operations to redistribute income to low-tax countries. If, when moving the tax base from another country to the country, the TNC estimates the change in profit as the amount of tax payments (TNCs $=1$ ), then in the country of their location, the counterfeit group of TNCs is observed (i.e., TNCs $=0$ ). Accordingly, the difference between the indicators of these groups makes it possible to estimate the amount of relocated profits and hence the size of the tax gap (Trusova et al., 2018) (11):

$$
A T T_{i}=E\left[T_{i} \mid M M E_{i}=1\right]=E\left[T_{i}(1) \mid M M E_{i}=1\right]-E\left[T_{i}(0) M M E_{i}=1\right] \forall_{i} \in I,
$$

where: $E\left[T_{i}(0) M M E_{i}=1\right] \forall_{i} \in I$ is a counterfeit factor that cannot be observed.

That is, is the difference between the tax payments T_i (1) of the $i$-th economic entity and the part of the multinational company (MME_i=1), obtained due to changes in the amount of profit and tax payments of the company in the normal mode of operation, as well as under the conditions of its transformation into a transnational company (when a domestic firm gets the opportunity to move tax bases between different tax bases) (Lutsenko, 2013). This effect can be represented by the formula (12):

$$
A T T_{i}=\frac{\left.\sum T_{1 . j}-\sum w(i, j) T_{0, j}\right) \times N C_{j=1} N T_{i=1}}{N T}
$$

where, $T_{1 . j}$ - tax payments of the $i$-th TNC, which is a part of the base group; $T_{0, j}$ is tax payments of a domestic company that is part of the control group; w(i,j) is the ratio between transnational and domestic companies (assigned a score of compliance); NT is the number of TNCs; $\mathrm{NC}$ is the number of domestic companies in the control group.

At the international level, in order to diagnose the degree of change in profits of economic entities (income taxpayers), it is proposed to use differential tax rates within the analyzed group, as the effect of the discrepancy between tax jurisdiction and preferential tax treatment is assessed only by comparing the effective tax rate of TNCs with an effective tax rate and a sample of domestic economic entities (Mazur, 2014). The assessment of the impact of the movement of the tax base on the profitability of the economic entity is based on the equation (13). The panel data model is as follows (14):

$$
\begin{gathered}
\text { Observed profit = true profit }+ \text { shifted profit, } \\
\text { Profibility }_{f, q, c, i, t}=\alpha X_{f, q, c, i, t}+\beta\left(S T A T_{c, t}-S T A T_{-} \text {group_avg }_{f, q, c, i, t}\right)+\delta_{t}+\delta_{i}+\phi_{f, q, c, i, t},
\end{gathered}
$$


where: Pr o fibility $f_{f, q, c, i, t}$ is the profitability of the $f$-th TNCs, belonging to the group $q$ in the country $c$ and industry $i$ in $t$ year; $X_{f, q, c, i, t}$ is a vector of characteristics of the f-th TNCs, belonging to the group $q$ in the country $c$ and industry $i$ in $t$ year; STAT $T_{c, t}-S T A T_{-} g r o u p \_a v g_{f, q, c, i, t}$ is the difference between the statutory income tax rate of economic entities of TNCs belonging to the group q in the country $\mathrm{c}$ in $\mathrm{t}$ year and the independent average rate in the country where TNCs are registered in $\mathrm{t}$ year; NT - the number of TNCs; $\delta_{t}, \delta_{i}$ - binary variables that take into account temporal and geographical (country of origin) fixed fiscal effects.

In practice, the estimated amount of income tax liability is a reduction of the tax liability by the amount of interest on the loan. This leads to the fact that TNCs prefer debt financing, because in the case of equity financing, these funds cannot be deducted from the amount of pre-tax profit (Baunsgaard and Keen, 2019; Lutsenko, 2013). The regression model of the optimal capital structure of TNCs, which reflects the tax and non-tax factors and information about the impact of taxation on the debt of the economic can be expressed as follows (Kriuchkova, 2016; Taxation Trends in the..., 2019) (15):

$$
\lambda_{i}=\alpha_{i}+\beta_{1} \tau_{i}+\beta_{2} \sum_{j \neq 1}^{n}\left(\tau_{i}-\tau_{j}\right) \rho_{j}+\phi_{i}, \quad i=1, \ldots, n,
$$

where: $\lambda_{i}$ is financial leverage of subsidiaries of TNCs; $\alpha_{i}$ is a fixed effect for the country; $\beta_{1} \tau_{i}-$ "internal" impact of taxation on leverage; $\beta_{2} \sum_{j \neq 1}^{n}\left(\tau_{i}-\tau_{j}\right) \rho_{j}$ is "international" influence (debt transfer) on the level of taxation; $\rho_{j}$ is the share of assets; $\phi_{i}$ is error.

\section{Results and Discussions}

We tested the hypothesis of synergy between the de-shadowization economy and fiscal policy of the world, which embodies the effect of tax gaps in economic entities in the formation of cash in circulation and its speed. The logical sequence of calculations in the first stage involves diagnosing the relationship between the need to consume the resources of economic entities in the world in the amount of free cash (additional financial resources) for the level of providing the de-shadowization base of income tax. For this, we used the function of dependence which is based on the hypothesis that the amount of resource consumption by economic entities (additional financial resources) and the effect of de-shadowization of tax gaps is determined by two components of economic development, i.e., formal and informal. As an indicator of the official economy, we used? the value of GDP per capita and the level of de-shadowization as an indicator of the informal sector.

The study of the volume of de-shadowization of tax gaps on the income tax of economic entities by the method of consumer circulation of free cash aims to compare the increase in domestic consumption of additional financial resources with the increase in profit. It is assumed that the increase in domestic consumption of free cash (additional financial resources) to ensure the deshadowization of the income tax base should correspond to the increase in profits of economic entities. If there is an excess of the growth of domestic consumption of additional financial resources over the growth of profits, it is considered that the amount of cash is directed to production in the deshadowization of the economy. Figure 2 shows the features of the ratio of de-shadowization and official sectors of the economy with the consumption of free cash depending on the level of state regulation of the money supply in the country's market and its economic development. 


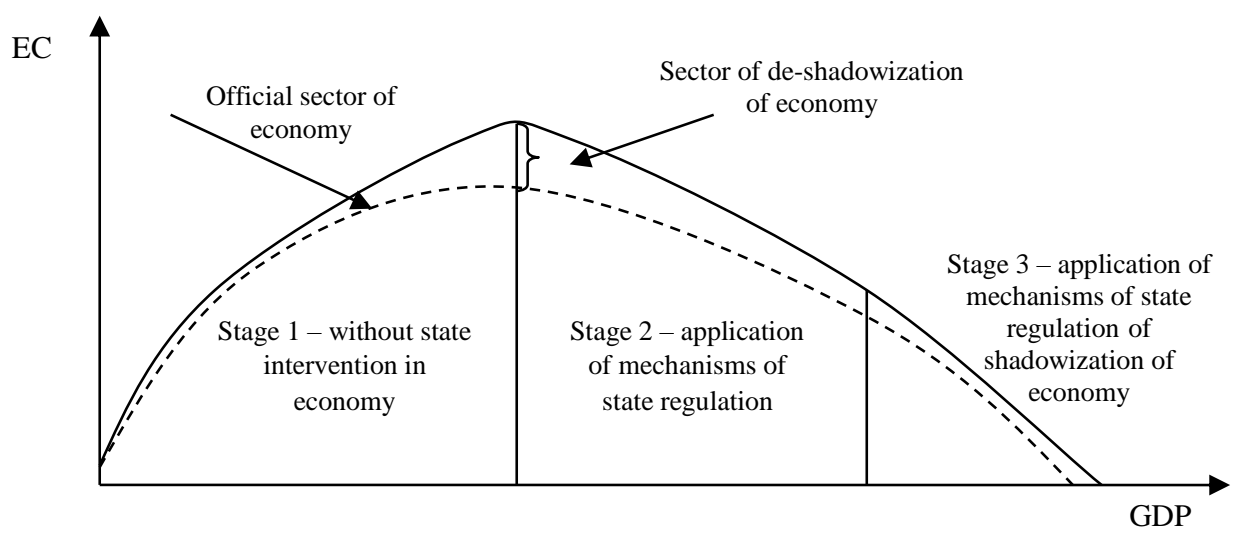

Figure 2. The ratio of de-shadowing of the economy and consumption of additional financial resources by stages of development of the country.

Source: Authors.

This assumption is true provided that the technological level of production of goods, works and services remains unchanged. Thus, in the case of investing in strategic alternatives to deshadowing of tax gaps, the difference between the index of change in domestic consumption of additional financial resources and the index of change in GDP increases, given the limited period of use of fiscal innovations in the economy. The basis for the calculations is the official data of the World Bank and the European Commission. The assessment of the relationship or steady-state between variables will be based on cointegration techniques. Determining the existence of relationships between time series will be done using the method of autoregressive distributed distances (ARDL). The ARDL equation is as follows (Shadow economy contributes..., 2017) (16):

$$
\operatorname{InE} C_{t}=\beta_{0}+\sum_{i=0}^{m} \beta_{1 i} \operatorname{InE} C_{t-1-i}+\sum_{i=0}^{n} \beta_{2 i} \operatorname{InSE}_{t-i}+\sum_{i=0}^{0} \beta_{3 i} I N G D P_{t-i}+\sum_{i=0}^{p} \beta_{4 i} I n I R_{t-i}+\varpi D U_{t}\left(T_{b}\right)+\varepsilon_{t},
$$

where: $D U_{t}$ is is a fictitious variable representing a structural fracture $\left(T_{b}\right.$ year of break $=$ 2005); EC is consumption of additional financial resources that provide the level of de-shadowization of tax gaps; SE is de-shadowization of the economy; IR is part of innovative IT technologies in use; GDP represents Gross Domestic Product.

We used a $F$-test to examine the joint integration of the variables of the null hypothesis, i.e., the common beta is zero (i.e., $b_{1}=b_{2}=b_{3}=0$ ). Critical values $F$ have lower and upper limits to check for interoperability. If the calculated value $F$ is lower than the value $F$ of the lower limit, then the null hypothesis cannot be rejected; if the calculated value $F$ exceeds the value $F$ of the upper limit, the null hypothesis of absence of common integration will be rejected (Shadow economy contributes..., 2017) (Eq. 17):

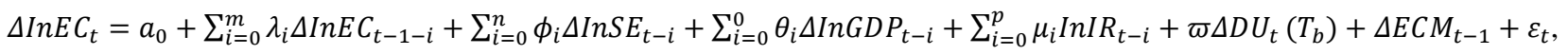

The coefficient $E C M_{t-1}$, in equation (17) shows the rate of adjustment of the parameter and indicates the rate of its conversion into equilibrium. The sign of the coefficient must be negative and significant.

According to the results obtained, the value $F$-statistics for all countries of the world is less than the value $F$-critical for $1 \%, 5 \%$ and $10 \%$, respectively. Thus, the results of testing by the method of Dickie-Fuller (ADF) and Phillips Perron (PP) indicate the stationary nature of all data for the EU and Ukraine (Figure 3-4) 


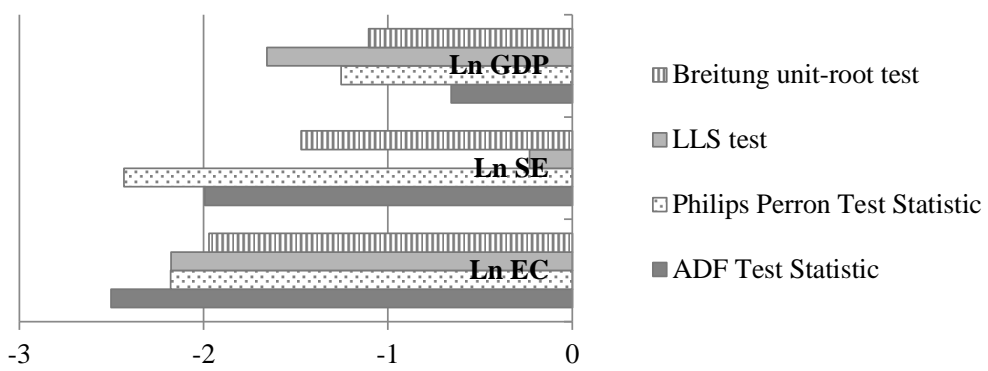

Figure 3. Level of unit (Ln) testing of variables of de-shadowization of tax gaps from indicators of the financial and economic development of Austria

Source: Authors.

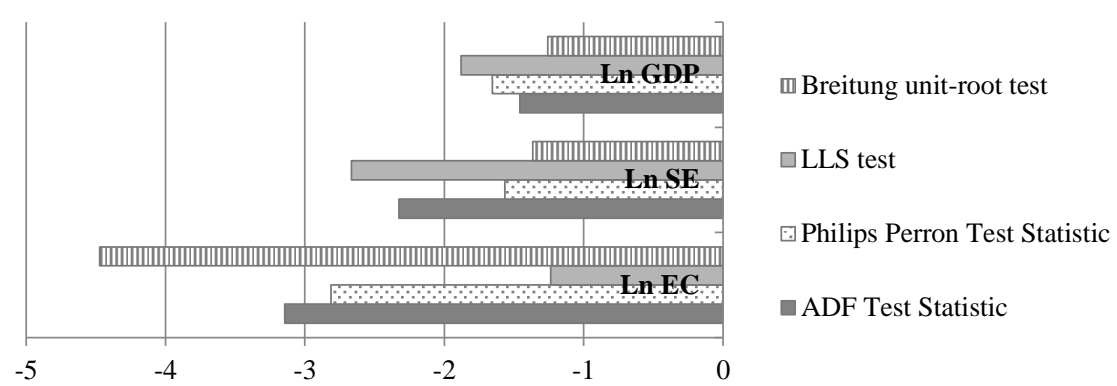

Figure 4. Level of unit testing of variables of de-shadowization of tax gaps from indicators of the financial and economic development of Ukraine

Source: Authors.

The results of the Breish-Godfrey test (Figure 5) indicate the absence of periodic autocorrelation. In addition, diagnostic testing of variables also showed a relationship between the analyzed indicators in the short term and their absence in the long term.

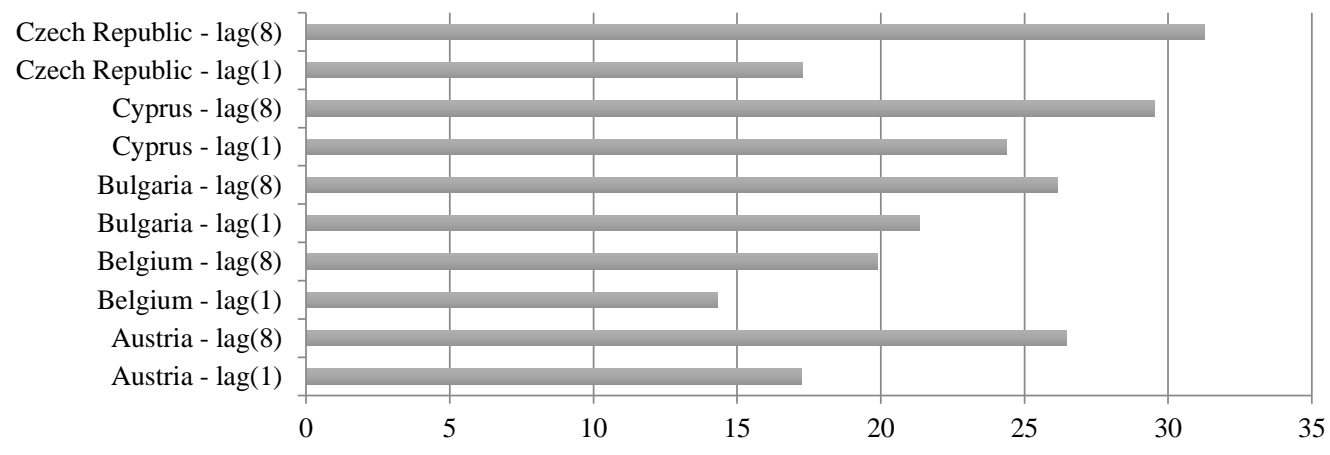

Figure 5. Brush-Godfrey correlation testing by Lagrange multiplier (LM)-level of dependence of variables of de-shadowization of tax gaps from indicators of the financial and economic development of Austria, Belgium, Bulgaria, Cyprus, Czech Republic

Source: Authors.

Given the statistically significant relationship between the analyzed indicators, it is proposed to calculate the effect of de-shadowing of tax gaps in the economy by formula (Shadow economy contributes..., 2017) (18):

$$
G A P_{i}=\frac{\frac{E C_{1}}{E C_{0}}-\left(\frac{C I_{1}}{C I_{0}}+\lambda+\gamma\right)}{\frac{C I_{1}}{C I_{0}}}
$$

where: $E C_{1}$ is the volume of domestic consumption of additional financial resources in the reporting period; $E C_{0}$ is the volume of domestic consumption of additional financial resources of the previous period; $C I_{1}$ is the adjusted index of change in the volume of profits of economic entities; 
$C I_{0}$ is the index of change in resource costs for IT technologies; $\lambda$ is the difference between the adjusted index of change in the volume of profits of economic entities and the index of change in resource costs for IT technologies; $\gamma$ is the difference between the adjusted index of change in the volume of profits of economic entities and the index of change in resource costs for the implementation of IT technology.

The calculations indicate a fairly high level of de-shadowization of tax gaps on corporate income tax in the vast majority of EU countries. Ukraine, as a non-EU country, has the highest level of the informal (shadowization) sector of the economy, i.e., 35-40\%. At the same time, Germany (89\%), the Netherlands (8.7-9\%) and Austria (11-12\%) have the lowest level of de-shadowing gaps in corporate income tax (Trusova et al., 2017).

\section{Conclusion}

1. Current trends in the development of de-shadowization of tax gaps in the systemcompositional model of fiscal policy of Ukraine are characterized by instability of economic entities, due to low efficiency of economic, political and social reforms, increasing losses of economic entities and?? corruption.

2. One of the most influential factors today is the de-shadowization of the economy. The financial flows most often serve as an object of manipulation of economic entities and, as a result, significantly restrain investment processes in the country, limit the pace of economic development and significantly reduce the effectiveness of reforms.

3. Given the importance of the management component in ensuring the effectiveness of de-shadowization of tax gaps to free up additional financial resources in IT technology, it is a prerequisite to develop and implement fiscal policy measures in the state.

\section{References}

1. Baunsgaard, T., and Keen, M. 2019. "Tax revenue and (or?) trade liberalization." IMF Working Paper No. 05/112. http://papers.ssrn.com/sol3/papers.cfm?abstract_id=887981 [2021-01-20].

2. Bohatyrova, Ye.M. 2016. "Tax reforms in Ukraine: effectiveness and strategic guidelines." Efficiency of Public Administration, 4: 322-328.

3. Brooks, Ch., Godfrey, Ch., Hillenbrand, C., and Money, K. 2016. "Do investors care about corporate taxes?" Journal of Corporate Finance, 38: 218-248. https://doi.org/10.1016/j.jcorpfin.2016.01.013

4. Cpa, I.B. 2015. "An evaluation of the impact of corruption: Tax burden and income on the size of the shadow economy." International Journal of Accounting and Taxation, 3(2): 15-27.

5. Dunets, A.N., Vakhrushev, I.B., Sukhova, M.G., Sokolov, M.S., Utkina, K.M. and Shichiyakh, R.A. 2019. "Selection of strategic priorities for sustainable development of tourism in a mountain region: Concentration of tourist infrastructure or nature-oriented tourism." Entrepreneurship and Sustainability Issues, 7(2): 1217-1229.

6. Enste, D.H. 2015. "The shadow economy in industrial countries." IZA World of Labour, 127: 1-10.

7. Harremi, M. 2014. “A simple analysis of the tax gap Balkan region.” Mediterranean Journal of Social Sciences, 5(19): 365.

8. Ivanishina, O.S., and Hirna, M.S. 2018. "Tax instruments for implementing the anti-crisis policy: international experience and opportunities in Ukraine." Scientific Bulletin of Mukachevo State University. Series “Economics”, 2(10): $128-133$.

9. Kriuchkova, N.M. 2016. "Forecasting of fiscal efficiency in the conditions of uncertainty of economic development." Bulletin of Odessa National University: Series “Economy”, 21(7-2(49)): 13-18.

10. Krysovatyi, A.I., Melnyk, V.M., and Koshchuk, T.V. 2014. Tax transformations in the EU and tax policy of Ukraine in the context of European integration. Ternopil: TNEU.

11. Kucheryavenko, M.P., and Smychok, Ye.M. 2019. "Moment of execution of the duty to pay taxes and fees: a tax-legal aspect." Journal of the National Academy of Legal Sciences of Ukraine, 26(1): 25-35.

12. Lutsenko, I.S. 2013. "Methodical approach to assessing the level of tax security of the state." Scientific Bulletin of Kherson State University, 2(41): 118-126.

13. Mazur, O.A. 2014. "Shadow economy in Ukraine: causes, forms of its manifestation and volumes." Bulletin of Dnipropetrovsk University: Series “Economics”. http://www.vestnikdnu.com.ua/archive/201482/70.html [2021-01-20].

14. Mitra, Sh. 2017. "To tax or not to tax? When does it matter for informality?" Economic Modelling, 64: 117-127. https://doi.org/10.1016/j.econmod.2017.02.024 
15. Panura, I.V. 2019. "To the issue of tax consulting." Scientific Bulletin of Mukachevo State University. Series “Economics", 1(11): 138-141.

16. Shadow economy contributes to over $10 \%$ of UK $\quad$ GDP. 2017. http://www.accaglobal.com/gb/en/news/2017/june/uk-shadow-economy.html [2021-01-20].

17. Sheverdin, M.M. 2018. "Historical and legal analysis of the direct mechanism taxation in the $90-\mathrm{S} X X$ cent. in Ukraine." Journal of the National Academy of Legal Sciences of Ukraine, 25(2): 13-26.

18. Sokolovska, A.M. 2012. "Formation of tax policy in conditions of uncertainty." Finance of Ukraine, 11: 44-51.

19. Taxation Trends in the Union. 2019. https://ec.europa.eu/taxation_customs/sites/taxation/files/taxation_trends_report_2019.pdf [2021-01-20].

20. Trusova, N., Kalchenko, S., Tsap, V., Ternovsky, V., and Levchenko, O. 2017. "Restrictions of financing the budget deficit of Ukraine." International Journal of Economic Research, 14(14): 353-364.

21. Trusova, N.V., Karman, S.V., Tereshchenko, M.A., and Prus, Yu.O. 2018. "Debt burden of the financial system of Ukraine and countries of the Eurozone: Policy of regulating of the risks." Espacios, 39(39): 312-328.

22. Trusova, N.V., Kohut, I.A., Osypenko, S.A., Radchenko, N.G., and Rubtsova, N.N. 2019. "Implementation of the results of fiscal decentralization of Ukraine and the countries of the European Union." Journal of Advanced Research in Law and Economics, 6(44): 1649-1663.

23. Vatamaniuk, O.S. 2018. Aggressive tax planning: negative consequences and the directions of countermeasures. Bulletin of Mukachevo State University. Series "Economics", 1(9): 153-158.

Natalia V. Trusova, Oksana V. Hryvkivska, Nataliia V. Polishchuk, Svitlana V. Skrypnyk, Iryna F. Lobacheva, Olena M. Kudyrko

\section{Mokesčių spragų panaikinimas valstybės fiskalinès politikos sistemos-kompozicijos modeliuose}

Anotacija

Straipsnyje nagrinėjami empiriniai mokesčių spragų panaikinimo lygio skaičiavimai valstybès fiskalinès politikos sistemos ir kompozicijos modelyje. Metodinis požiūris ị mokesčių spragų panaikinimo lygio integravimą i fiskalinès politikos sistemos-kompozicijos modeli yra pagrịstas, atsižvelgiant i strateginius valstybès finansinio ir ekonominio vystymosi veiksnius. Strateginių alternatyvų, skirtų panaikinti mokesčių spragoms valstybės fiskalinès politikos sisteminiame ir kompoziciniame modelyje, pasirinkimo modelis, kaip tarpusavyje susijusių ir vienas kitą papildančių biudžeto ir mokesčių srities rodiklių architektonika, atkuria bendrujų finansų ir ekonomikos raidą lemiančių veiksnių grandinę. būsena. Pateikiamas integruoto strateginių alternatyvų rodiklio apskaičiavimo metodas, kuris atspindi modifikuotos fiskalinių naujovių sistemos konfigūraciją, susijusią su ūkio subjektų apmokestinimu. Siūlomas metodinis metodas, leidžiantis ịvertinti ūkio subjektų pajamų mokesčio mokesčių atotrūkio panaikinimo lygị.

Natalia V. Trusova - Full Doctor in Economics, Professor at the Department of Finance, Banking and Insurance, Dmytro Motornyi Tavria State Agrotechnological University, Melitopol, Ukraine.

E-mail: nv.trusova6607@tanu.pro

Oksana V. Hryvkivska - Full Doctor in Economics, Head of the Department of Economics, Ecology and Practical Entrepreneurship, European University, Kyiv, Ukraine.

E-mail: oks.hryvkivska@uohk.com.cn

Nataliia V. Polishchuk - Full Doctor in Economics, Head of the Department of Finance, Vinnytsia Finance and Economics University, Vinnytsia, Ukraine.

E-mail: n_polishchuk@uohk.com.cn 
Svitlana V. Skrypnyk - PhD in Economics, Head of the Department of Accounting and Taxation, Kherson State Agrarian and Economic University, Kherson, Ukraine.

E-mail: sskrypnyk@tanu.pro

Iryna F. Lobacheva - PhD in Economics, Associate Professor at the Department of Accounting and Taxation, Vinnytsia Institute of Trade and Economics, Kyiv National University of Trade and Economics, Vinnytsia, Ukraine.

E-mail: prof.lobacheva@uohk.com.cn

Olena M. Kudyrko - PhD in Economics, Associate Professor at the Department of Accounting and Taxation, Vinnytsia Institute of Trade and Economics, Kyiv National University of Trade and Economics, Vinnytsia, Ukraine.

E-mail: o.kudyrko@uohk.com.cn

Natalia V. Trusova - Ekonomikos mokslų daktarè, profesorè, Finansų, bankų ir draudimo katedra, Valstybinis Dmytro Motornyi Tavria žemès ūkio technologijų universitetas, Melitopol, Ukraina.

E-mail: nv.trusova6607@ tanu.pro

Oksana V. Hryvkivska - Ekonomikos mokslų daktarè, katedros vedèja, Ekonomikos, ekologijso ir praktinès entreprenerystès katedra, Europos universitetas, Kijevas, Ukraina.

E-mail: oks.hryvkivska@uohk.com.cn

Nataliia V. Polishchuk - Ekonomikos mokslų daktarè, katedros vedèja, Finansų katedra, Vinnytsia finansų ir ekonomikos universitetas, Vinnytsia, Ukraina.

E-mail: n_polishchuk@uohk.com.cn

Svitlana V. Skrypnyk - Ekonomikos mokslų daktarè, katedros vedejja, Apskaitos ir mokesčių katedra, Vlastybinis Kherson -emès ūkio ir ekonomikos universitetas, Kherson, Ukraina.

E-mail: sskrypnyk@ tanu.pro

Iryna F. Lobacheva - Ekonomikos mokslų daktarè, docentė, Apskaitos ir mokesčių katedra, Vinnytsia prekybos ir ekonomikos institutas, Nacionalinis Kijevo prekybos ir ekonomikos universitetas, Vinnytsia, Ukraina.

E-mail: prof.lobacheva@uohk.com.cn

Olena M. Kudyrko - Ekonomikos mokslų daktarè, docentè, Apskaitos ir mokesčių katedra, Vinnytsia prekybos ir ekonomikos institutas, Nacionalinis Kijevo prekybos ir ekonomikos universitetas, Vinnytsia, Ukraina.

E-mail: o.kudyrko@uohk.com.cn 